\title{
The Role of Test Taking Strategies in Improving Omani Students' Listening Comprehension
}

\author{
Aisha Al Bulushi ${ }^{1}$, Fawzia Al Seyabi ${ }^{2}$ \& Saleh Al-Busaidi ${ }^{2, *}$ \\ ${ }^{1}$ Ministry of Education, Sultanate of Oman \\ ${ }^{2}$ College of Education, Sultan Qaboos University, Sultanate of Oman \\ *Correspondence: College of Education, Sultan Qaboos University, Sultanate of Oman. \\ E-mail: asad@squ.edu.om
}

Received: May 29, 2018 Accepted: July 17, 2018 Published: November 14, 2018

doi:10.5296/ije.v10i4.13951 URL: https://doi.org/10.5296/ije.v10i4.13951

\begin{abstract}
This quasi-experimental study investigated the effect of using test taking strategies on Omani grade 11 students' performance in listening comprehension tests. It also documented the perceptions of the students regarding the importance of the test taking strategies in listening comprehension tests and their employment of these strategies in general. The sample of the study included two groups, one control and one experimental, from grade 11 students from a government school in the school year 2016-2017. Two research instruments were used to collect data: a listening comprehension test and a student perceptions questionnaire. Data analysis revealed that the students in the experimental group outperformed their counterparts in the control group in the listening comprehension test. Furthermore, the students in the experimental group perceived using the test taking strategies in the listening comprehension tests as being very important. Also, the results of the questionnaire showed that the students' use of the various kinds of cognitive, metacognitive, and affective strategies for: before, during, and after the listening ranged from "high" to "very high" degrees of use.
\end{abstract}

Keywords: Tests, Test taking strategies, Listening comprehension, Oman, Grade 11 students 


\section{Introduction}

Listening plays an essential role in foreign language learning, as it is one of the four main skills for language acquisition. It is, however, not an easy skill to acquire because it requires listeners to make meaning from the oral input they are exposed to by drawing upon their background knowledge of the world and of the foreign language they learn (Young, 1997). Testing students' listening abilities can also pose challenges to students in foreign language contexts. Aldera (2015) asserts that students may struggle when attempting listening comprehension tasks and this is because of the different aspects of the English language such as "variety of pitch, intonation, stress, and different vocabulary" (Aldera, 2015, p.1983). Students are not well equipped with strategies that enable them to comprehend the listening tasks in the tests. Research suggests that the students should be informed about the proper techniques which can help in overcoming such difficulties in listening comprehension (Aldera, 2015; Liu, 2008; Vandergrift \& Tafaghodtari, 2010). Teaching students various learning strategies to employ during tests can help them in their assessment (Al-Saifi, 2008), especially that people today are required to take more tests throughout their school, college and career lives than ever before.

However, EFL teachers are not fully aware of the importance of teaching their students listening techniques and strategies (Ahour \& Bargool, 2015). So, there is a serious need for training students to use test taking strategies in the listening comprehension as most listening researchers agree that using test taking strategies is essential when answering listening tasks (Hinkel, 2006; Aldera, 2015; Y1lmaz \& Yavuz, 2015). The literature states that test taking strategies have a positive impact on the students' test taking competency, improving their academic achievement, and reducing anxiety associated with tests (Al-Saifi, 2008; Dodeen, Abdelfattah, \& Alshumrani, 2014). Despite the importance of test taking strategies, "they are noticeably neglected in EFL/ESL testing literature" (Amer, 2007, p.1).

This seems to be the case in the Omani context. In a preliminary investigation by the researchers in some government schools using informal interviews with teachers revealed that EFL teachers are left with little time to train their students with different strategies for listening comprehension. Also, some teachers in the schools typically follow the "listen, respond, and check" pattern. They teach listening by first introducing the topic, playing the $\mathrm{CD}$, asking students to respond to questions, and checking students' answers. Teachers rarely train their students to use listening strategies to develop their listening comprehension. In addition, Omani students find listening comprehension to be very challenging (Al-Busaidi, 1997), especially when responding to listening tests. Students, even the excellent ones, complain about the difficulty of listening tests. Moreover, students frequently score low marks in grade ten listening tests as shown by an analysis of listening comprehension tests by the researchers. This could be a result of the lack of strategy training. Previous studies in the Omani school system indicate the insufficiency of integrating test taking strategies in the English curriculum, and that students need more training in order to practice these strategies (Al-Saifi, 2008; Bait-Obiedoon, 2002). Consequently, there is a demand to engage the students in a training program that fulfils their needs in the area of listening comprehension, and provides them with test taking strategies for the listening tests. 


\section{Literature Review}

Test taking strategies are not new in the field of ELT research and scholars have been describing these strategies since the latter part of 1970s (Dodeen, Abdelfattah, \& Alshumrani, 2014). According to Cohen (2007), test taking strategies are learning strategies that test-takers can use when completing language tests. The main purpose of teaching test taking strategies is to "help students to translate their knowledge from classroom learning to answering and responding to questions when taking tests" (Dodeen, Abdelfattah, \& Alshumrani, 2014, p.1). Also, according to Rahimi and Katal (2012), the students who use various sorts of test taking strategies such as metacognitive strategies can achieve better learning outcomes because these strategies assist them in planning, controlling, and evaluating their learning.

In the listening comprehension tests, the test-takers are expected to demonstrate a reasonable level of comprehension of the spoken language. This is because listening comprehension tests are widely used in the second language assessment (Aryadoust, 2012). So students need some strategies and tactics in order to deal with listening comprehension tests (Rahimirad, 2014). Rahimirad (2014) concluded that training students to use some test taking strategies may facilitate the students' listening performance and improve their learning results as well.

According to Amer (2007), there are two test taking strategy taxonomies mentioned in the EFL/ESL literature. The first taxonomy is proposed by Cohen (1998) and the second one is proposed by Bachman and Palmer (1996).

\subsection{Cohen's Taxonomy}

Cohen (1988) classified second language learner strategies into second language learning strategies and second language use strategies. Language learning strategies are strategies used to distinguish materials that learners must learn from other materials where they group the material in ways that allow them to learn it easily, revise the material several times, or use memory techniques to learn the material. On the other hand, language use strategies include strategies for using the material which are comprised of 4 techniques: retrieval strategies used to recall materials; rehearsal strategies used to rehearse structures; cover strategies used to show control over material; and communication strategies used to produce meaningful messages to audience. Cohen (1988) demonstrated that such strategies are applied to test taking strategies as students need to retrieve the material for the test, rehearse it, use cover strategies to look good and communicate if the test requires so (cited in Amer, 2007).

\subsection{Bachman and Palmer's Taxonomy}

Bachman and Palmer (1996) described test taking strategies as metacognitive strategies and divided them into three groups including goal setting strategies, assessment strategies, and planning strategies. With goal setting strategies, students identify the tasks within the test, choose a task from all possible tasks, and decide whether to complete it. Students use assessment strategies for different purposes. Assessing the characteristics of a task to decide whether to complete it, what is needed to complete specific tasks, assessing the availability of relevant knowledge needed to complete the task, and assessing the suitability of their 
responses to the test. Students use planning strategies to decide how to use what they have by selecting the most appropriate elements from the knowledge they have to complete the task. They also formulate a plan to use such elements and select a plan to respond to the specific tasks. However, Amer (2007) asserts that due to the lack of empirical evidence to support Cohen's (1988) and Bachman and Palmer's (1996) taxonomies of language test taking strategies, researchers use Oxford's (1990) taxonomy of language learning strategies as a reference. Oxford (1990) divided her taxonomy into cognitive, meta-cognitive, affective, and social strategies. The cognitive strategies involve elements like prediction, deductive reasoning, and summarization. They also include the implementation of scheme, inference, classification, and taking notes as well (Henna, 2012). These strategies enable the learners to better understand the language (Oxford, 1990). They can help the second language learners in an academic context with the academic listening tasks as well (Chamot, 2004). The metacognitive strategies are the mental processes used to consciously control the cognitive strategies for better test performance (Rahimirad, 2014; Hanna, 2012). They include concentration, planning, monitoring, assessment, and evaluation of the learning (Rahimirad, 2014; Hanna, 2012). Also, Rahimirad (2014) asserts that it is crucial to apply the metacognitive strategies in learning. The affective strategies are concerned with students' feelings and emotions, while the social strategies increase interaction with the language (Oxford, 1990). Also, Chamot (1995) states that the social affective strategies comprise building self-confidence while doing the test, positive thinking, and having the courage to ask for clarifications (as cited in Chamot, 2004).

A number of studies have examined the factors that can lead to successful performance in listening comprehension tests, such as the use of test taking strategies, the familiarity of the topics, the test takers' backgrounds, and the use of schemata to relate the oral messages to the real world (Aryadoust, Goh, \& Lee, 2011; Bachman, 1990; Goh \& Aryadoust, 2010; Vandergrift \& Tafaghodtari, 2010; Haladyna \& Downing, 2004; Rahimirad, 2014). In a study by Vandergrift and Tafaghodtari (2010), the researchers found that skilled listeners tend to use metacognitive strategies when dealing with the listening tasks more than the less skilled listeners. Similarly, a study was carried out by Al Mamari (2009) to explore the effectiveness of using mobile learning technologies on students' listening skills in higher education in Oman. The major finding of his study was that using mobile learning devices is effective in improving the students' listening skills. In addition, many studies show that using strategies to deal with listening comprehension tests can be of great help to improve the students' proficiency levels (Cross, 2009; Vendergrift, 1997). Coskun (2010) asserts that teaching students how to use strategies when doing listening comprehension tests is crucial and would lead to development in the students' listening abilities. So, there is a strong relationship between using test taking strategies and the high levels in listening comprehension tests.

A study conducted by Vandergrift (2003), revealed that skilled listeners tend to use more metacognitive strategies such as planning and evaluating when answering listening tasks and more advanced level students use a greater number of overall test taking strategies in listening tests. Both Coskun (2010) and Vandergrift (2003) perceived using various strategies in tests as crucial and beneficial as well. Moreover, the frequency of the strategies used in 
listening comprehension tests depends on the difficulty of the task itself (Barkaoui at al., 2013). That is to say, the students tend to use various sorts of strategies when they face difficult listening tasks. So, the students' use of test taking strategies in listening comprehension tests differ with regard to their levels and the types of the listening tasks they do.

On a similar vein, Pan and In'nami (2015) examined strategy use in relation to the language proficiency, types of test task, and students' performance in listening tests among 170 university students in Taiwan. The researchers used Test of English for International Communication (TOEIC) and designed questionnaires in order to measure the students' use of cognitive and metacognitive strategies in listening tests. They found that some strategies such as inference and elaboration were used with the same frequency levels, while other strategies like evaluation and planning were mostly used by advanced learners. So, there were differences in strategy use with regard to the types of the strategies and the students' levels as well.

Even though different scholars call for the use of test taking strategies, these strategies are still not well researched in EFL/ESL testing literature (Amer, 2007). Furthermore, teachers neglect teaching these strategies in schools because they do not consider them important for the students (Al-Saifi, 2008). The present study intended to add to the literature on this topic by investigating the use of test taking strategies in the Omani educational context.

\section{Method}

\subsection{Design}

This study attempted to answer two research questions: a) what is the effect of test taking strategy training on improving grade 11 students' listening comprehension?; and b) what are the students' perceptions towards the use of test taking strategies in improving listening comprehension? The study employed a quasi-experimental research design to investigate the impact of using test-taking strategies on Omani grade 11 students' achievement in listening comprehension tests.

\subsubsection{Population and Sample}

The population of the study was grade 11 female students in Al-Batinah North Governorate, which constituted 4,056 students, in the academic year 2016-2017. The sample of the study consisted of two intact classes from a pool of grade 11 classes. The two intact classes were chosen based on their achievement levels in the previous semester's listening comprehension tests. It is worth mentioning that the two classes were taught by different teachers in order to reduce the extraneous variables of the experiment. Also, these two teachers had a similar amount of teaching experience as both taught EFL in Omani schools for six years. They were also similarly qualified according to their last performance report. 


\subsubsection{Instruments}

There were two instruments used to collect data for the study. In addition, a teacher's guide was developed for strategy training.

The Listening Comprehension Test

A listening comprehension test was used to investigate the effect of test-taking strategy training on the students' achievement in listening comprehension tests. The test was developed based on the previous year's grade 11 specifications set for listening tasks available from the Evaluation Department in the Ministry of Education in Oman. The test consisted of two sections and the test items were of different comprehension levels in order to suit the different student proficiency levels. The listening scripts were taken and modified from www.ieltsbuddy.com. It is also worth mentioning that the topics of the listening were related to the themes of the units of the Engage with Me syllabus, the main textbook used by the Ministry of Education in Oman. The listening comprehension test was administered to both groups as a pre-test to verify the homogeneity and the equivalence of the two groups in their level of listening comprehension. The same test was used in the experiment as a post-test.

Both validity and reliability of the test were established. The items of the listening comprehension test were validated by a number of jury members from different educational sectors. As for reliability, the listening comprehension test was administered to a pilot group of 24 grade 11 students at a Post Basic School in Al-Batinah North Governorate. A test/re-test correlation coefficient was used to measure the reliability of the listening comprehension test. The Pearson correlation was found to be 0.85 , which is significant at the 0.01 level.

\subsubsection{The Questionnaire}

The second instrument was a questionnaire administered to the experimental group in order to uncover students' perceptions about the use of test taking strategies in completing the listening comprehension tests. The questionnaire consisted of two parts. The first part investigated students' perceptions regarding the importance of the strategies using 12 statements. The students had to express their opinion using a five-point Likert scale where $5=$ Strongly agree (SA), 4= Agree (A), 3= Undecided (U), 2= Disagree (D), and 1= Strongly disagree (SD). The second part contained 31 statements. It asked students to indicate their use of "before listening", "during listening" and "after listening" strategies using a frequency scale where 5= Always (A), 4= Often (O), 3= Sometimes (S), 2= Rarely (R), 1= Never (N). To check its validity, the students' perceptions questionnaire was submitted to a panel of experts to judge its validity in terms of relevance, suitability, and clarity and was modified based on their feedback. As for reliability, the questionnaire was piloted to a group of 25 grade 11 students at a Post Basic School in Al-Batinah North Governorate. The internal consistency (Cronbach alpha coefficient) was used to measure the reliability coefficient which was found to be .80 , which indicates that the questionnaire was highly reliable. 


\subsubsection{The Teacher's Guide}

A teacher's guide was developed for the teacher of the experimental group to help her with the implementation of the test taking strategies in her listening classes. The teacher's guide included the goals of the test taking strategies on listening comprehension, the list of the strategies, and the sessions' plans for training the students on the use of test taking strategies in listening comprehension tests. There were 8 sessions to be implemented in 8 weeks, one session per week. Each of the sessions comprised three phases which were "before listening", "during listening", and "after listening". The specification for the timing of each session was 45 minutes for each session. The objectives and the materials to be used for each session were also specified. The teacher's guide came with 8 listening tests to be practiced when training the students.

The list of the test taking strategies designed for training the experimental group was based on previous studies and the related literature, mainly Oxford (1990), Vandergrift's (2003) cognitive and metacognitive strategies, O’Malley and Chamot (1990), Pan and In'nami (2015) and Al-Saifi (2008). The list consisted of 30 strategies and was divided into three main phases: 7 "before listening" strategies, 16 "during listening" strategies, and 7 "after listening" strategies. Also, each phase was divided according to the types of strategies proposed by Oxford (1990) which are direct strategies (cognitive strategies), indirect strategies (metacognitive), and affective strategies. The strategies are listed in the Appendix.

\section{Results}

\subsection{The Effect of the Training on Students' Performance in Listening Tests}

At the initial stages of the study and before the training session was run, the listening test was simultaneously administered to both control and experimental groups. Students' results were analyzed using an independent sample T-test in order to determine if the level of listening comprehension was the same for both. Table 1 below presents the independent sample T-test of the pre-test results of the control and the experimental group.

Table 1. An Independent-Sample t-test for the Experimental and Control Groups' Pre-Test Scores $(n=47)$

\begin{tabular}{llllllll}
\hline & Group & $n$ & $M$ & $S D$ & $t$ & $d f$ & $p$-value \\
\hline Pre-test & Experimental & 20 & 8.50 & 1.32 & .99 & 45 & .33 \\
& Control & 27 & 8.11 & 1.34 & & & \\
\hline
\end{tabular}

Based on the t-test results, there was no statistical significant difference in the scores for the experimental group $(M=8.50, S D=1.32)$ and the control group $(M=8.11, S D=1.34) ; t(45)$ $=.99, p=.33$, two tailed). This result reveals that both classes are equivalent in the level of listening comprehension before starting the actual training in test taking strategies. 
To see the effect of the training on using test taking strategies on students' performance in listening tests, a post listening comprehension test was administered to the experimental and control groups. Table 2 presents the independent-sample t-test for the experimental and control groups' post-test scores.

Table 2. An Independent-Sample t-test for the Experimental and Control Groups' Post-Test Scores $(n=47)$

\begin{tabular}{llllllll}
\hline & Group & $n$ & $M$ & $S D$ & $t$ & $d f$ & $p$-value \\
\hline \multirow{2}{*}{ Posttest } & Experimental & 20 & 12.25 & 1.25 & 3.44 & 45 & .001 \\
& Control & 27 & 11.15 & .95 & & & \\
\hline
\end{tabular}

There was a statistically significant difference between the scores of the experimental group and the control group, $t(45)=3.44, p=.001$, (two tailed). The magnitude of the difference in the means (mean difference $=1.10,95 \% C L: .46$ to 1.75$)$ was very large (eta squared $=0.21$ ) according to Cohen's (1988) guidelines.

The above results reveal that the experimental group, after learning the test taking strategies used in the listening comprehension tests, outperformed the control group in the post-listening comprehension test. These results can be aligned with the results of the study conducted by Vandergrift (2011) who found that the use of various strategies in listening tests improve the performance of the students including the less skilled students.

To obtain more details about the experimental and control groups' achievement, a paired-sample T-test was conducted to evaluate the impact of the intervention on the students' achievement in the listening comprehension test. Table 3 shows the paired sample T-test for the pre-test and post-test scores of listening comprehension test for the experimental and control groups.

Table 3. Paired Sample T-Test for the Pre-Test and Post-Test Scores of Listening Comprehension Test $(n=47)$

\begin{tabular}{llllllll}
\hline Group & & $n$ & $M$ & $S D$ & $t$ & $d f$ & p-value \\
\hline \multirow{2}{*}{ Experimental } & Pretest - & 20 & 8.50 & 1.32 & -9.97 & 19 & .000 \\
& Posttest & 20 & 12.25 & 1.25 & & & \\
\multirow{2}{*}{ Control } & Pretest - & 27 & 8.11 & 1.34 & -10.14 & 26 & .000 \\
& Posttest & 27 & 11.15 & .95 & & & \\
\hline
\end{tabular}

Regarding the experimental group, there was a statistically significant increase in the students' scores from the pre-test to the post-test, $t(19)=-9.97, p<.0005$ (two-tailed). The mean increase in the post-test was 3.75 points with a $95 \%$ confidence interval ranging from -4.54 to -2.96. The eta squared statistic (0.84) indicated a large effect size, according to Cohen's (1988) 
guidelines. This means that students have benefited from using the test taking strategies in the listening comprehension test.

It is also important to mention that there was a statistically significant increase in the control students' scores from the pre-test to the post-test, $t(26)=-10.14, p<.0005$ (two-tailed). The mean increase in the posttest was 3.04 points with a $95 \%$ confidence interval ranging from -3.65 to -2.42 . The eta squared statistic (0.81) indicated a large effect size, according to Cohen's (1988) guidelines. This means that even the students in the control group have benefited from having more sessions in listening practice but the students in the experimental group seemed to benefit more from the strategy instruction they received, as indicated in the results presented in Table 2 above.

\subsection{Students' Perceptions towards Test Taking Strategies}

In order to investigate students' perceptions of using test taking strategies in listening, the students' perceptions questionnaire was administered to the experimental group after the intervention was completed. Table 4 presents the means and the standard deviations of the items related to the first part of the questionnaire which is related to test taking strategies such as their usefulness, importance, students' enjoyment of them, students' ability to transfer their use to other skill areas as well as students' perceptions of the usefulness of the training they received on test taking strategies.

Table 4. Means and Standard Deviations for the Importance of Using the Test Taking Strategies in the Listening Comprehension Tests $(n=20)$

\begin{tabular}{llll}
\hline Statements & $M$ & $S D$ \\
\hline 1. I have learned more about using test taking strategies for the & 4.6 & .5 \\
listening tests. & & \\
2. Using test taking strategies will help me get better grades in & 4.5 & .6 \\
the listening tests. & 4.3 & .5 \\
3. I now feel more confident when dealing with listening tests & & \\
$\quad \begin{array}{l}\text { after learning about test taking strategies. } \\
\text { 4. I can transfer the use of test taking strategies to other skill }\end{array}$ & 4.2 & .8 \\
& $\begin{array}{l}\text { areas like reading. } \\
\text { 5. I enjoyed learning about test taking strategies used in the }\end{array}$ & 4.2 & .7 \\
& $\begin{array}{l}\text { listening tests. } \\
\text { 6. The training on using the test taking strategies was useful. }\end{array}$ & 4.2 & 1.7 \\
\hline
\end{tabular}

Table 4 shows that all mean scores are between the scale values $4.20-5$, indicating that all of the students perceived using the test taking strategies in listening comprehension as very important. The highest mean score of 4.65 is recorded for the statement "I have learned more about using test taking strategies for the listening tests." This reveals that after the intervention, the participants of the study gained more understanding regarding the use of test taking strategies in listening comprehension tests. They also perceived using test taking 
strategies as a possible reason for getting high scores in listening tests. This finding is consistent with the conclusion that Amer (1993) and Al-Saifi (2008) drew in their studies. Furthermore, the frightening atmosphere of tests has disappeared, as the students feel more relaxed and confident when dealing with listening comprehension tests. Actually, this result is in line with what Al-Saifi (2008) found in her study where students developed positive attitudes towards English language tests in general and they felt more confident when approaching tests after the treatment. The results also show that the students enjoyed having such training, as it was useful for them. Furthermore, the use of test taking strategies is not limited to the listening skill and it can be transferred to other skill areas such as reading. Al-Saifi (2008) also found that students could apply test-taking strategies with tests on other subjects like mathematics and Arabic exams.

The students' perceptions of their own usage of test taking strategies were divided into 3 sections: before listening strategies, during listening strategies, and after listening strategies.

4.2.1 Before Listening Strategies

Table 5. Means and Standard Deviations for before Listening Strategies $(n=20)$

\begin{tabular}{lrr}
\hline Statements & M & SD \\
\hline Cognitive Strategies & & \\
1. I listen to the directions of the listening test very carefully before & 4.5 & 1.0 \\
answering the test. & & \\
2. I utilize grammatical structures to guess the meaning of the text. & 4.1 & .81 \\
3. I translate the instructions into Arabic. & 4.0 & .97 \\
4. I read the directions of the listening test very carefully before & 4.0 & .69 \\
answering the test. & 3.9 & 1.05 \\
5. I Preview the whole listening test before starting listening. & 3.7 & 1.45 \\
6. I take notes on the test paper. & & \\
\hline Affective Strategies & 4.5 & .61 \\
1. I try to lower my anxiety and relax before starting the test. & & \\
2. I encourage myself by positive statements like I can listen & 4.2 & .70 \\
clearly...etc. & &
\end{tabular}

Table 5, in general, illustrates that all of the students use all of the strategies they were trained in, as all of the mean scores are ranging between the high degrees of usage (3.40 -4.19) and the very high degrees of usage (4.20 - 5). The results can be interpreted in terms of cognitive and affective strategies.

\subsection{Cognitive Strategies}

Table 5 shows that the highest mean score (4.55) is for the statement: "I listen to the directions of the listening test very carefully before answering the test." This shows that the participants believed that listening to the directions of the test can be beneficial before they start answering the test. However, some cognitive strategies were used less often by the 
participants. For example, the lowest mean score (3.75) is for the statement "I take notes on the test paper." This result is not in line with the Ahour and Bargool (2015) study which emphasized the important role of the note-taking strategy in listening comprehension tests. Research on note taking has also shown that this is an area where students can receive training. In a study by Hayati and Jalilifar (2009), it was found that trained note-takers yield significantly better performance than untrained note-takers because they are instructed to take a more systematic approach towards note-taking. The relatively lower mean that this statement received may be attributed to the fact that the students tended to translate the instructions and other components of the test into Arabic as the mean score is 4.05 for this strategy. And this may result in the low use of the note-taking strategy.

Furthermore, the results reveal that not all of the students use the strategy of "Previewing the whole listening test before starting to listen", which Goh (2002) finds to be important because it helps the listeners avoid word recognition problems and leads them to process the input more quickly. This might be because of the time constraints during the listening test and the students may prefer to use other before listening strategies like translation. Another reason may be because of the similarities between the strategy of previewing the whole listening test and the strategy of reading the directions of the test items.

\subsection{Affective Strategies}

Table 5 shows that the highest mean score (4.55) also goes to the statement "I try to lower my anxiety and relax before starting the test" which is considered an affective strategy used by the students. Also, the second highest mean score (4.20) is counted for the statement "I encourage myself by positive statements like I can listen clearly...etc." This means that the participants of the study perceived the use of the affective strategies as being helpful and leads to understanding the listening more. These results concur with Goh (2002), Kassem (2015) and Riazi (2007), who encouraged the use of affective strategies before listening and emphasized the important role of relaxing in enhancing the students' focus. In addition, Harputlu and Ceylan (2014) declared that it is crucial to have confidence and self-encouragement before doing the listening test. They found that the students who experienced a high level of anxiety and lack of confidence were unlikely to succeed in listening comprehension tests.

\subsubsection{While/during Listening Strategies}

Table 6 shows that the mean scores for most of the strategies are convergent and fall under the high degrees of usage (3.40 - 4.19) and very high degrees of usage (4.20 - 5). This indicates that the students have learnt to use various forms of cognitive and metacognitive strategies while they are listening. 
Table 6. Means and Standard Deviations for While/During Listening Strategies $(n=20)$

\begin{tabular}{llc}
\hline Statements & $M$ & $S D$ \\
\hline Cognitive Strategies & & \\
1. I pay attention to the repeated words in the listening test. & 4.7 & .44 \\
2. I try to understand the main idea, and then the details. & 4.5 & .61 \\
3. I summarize or make an outline for what I hear. & 4.2 & .87 \\
4. I repeat the words/phrases that I hear. & 4.2 & .72 \\
5. I connect any new words with words that I already know. & 4.1 & 1.2 \\
6. I take notes and translate what I hear while listening. & 4.05 & 1.10 \\
7. I utilize the intonation, tone of voice and the word stress to guess & 4.0 & .97 \\
the vocabulary and text. & & \\
8. I utilize my prior knowledge/experience to understand the text. & 3.9 & .91 \\
9. I create a mental picture of the text in order to comprehend it. & 3.7 & 1.37 \\
\hline Metacognitive Strategies & & \\
1. When there is difficulty during the listening process, I don't give & 4.2 & 1.02 \\
2. I but rather I continue listening. & & \\
2. I listen to the script with my eyes closed. & 4.1 & .99 \\
3. I try to predict the incoming content by using the information & 4.0 & 1.05 \\
being delivered. & & \\
4. I listen to what is said without paying much attention to every new & 4.0 & 1.20 \\
5ord. & & \\
5. I try to relax to reduce the anxiety so that my concentration & 4.0 & 1.05 \\
increases. & & \\
6. I compare what is understood with what I know about the topic. \\
7. I skip over words that are not understood so that I don't miss what & 3.9 & 1.00 \\
is said next. & & .85 \\
\hline
\end{tabular}

\subsection{Cognitive Strategies}

Table 6 shows that the highest mean score (4.75) is recorded for the cognitive strategy "I pay attention to the repeated words in the listening test." This shows that the students can figure out the answers when they are stressed more than once. According to Goh (2002), the planning strategy in which the students decide on the input they want to pay attention to is useful before starting to listen. However, the lowest mean score (3.74) is for the statement "I create a mental picture of the text in order to comprehend it." This shows that perhaps not all of the students use this strategy because the time allotted is insufficient to create a mental picture for the text while they are listening. The results also reveal that most of the students use note-taking as a while listening strategy as the mean score for the statement of note-taking is (4.05) and the strategy has been shown to be effective in a study conducted by Ahour and Bargool (2015). In addition, the results show that the students utilize the intonation, tone of voice and the word stress to guess the vocabulary and according to Cohen (2007), this strategy is considered as part of test savvy techniques that the students can use to 
figure out the answer.

\subsection{Metacognitive Strategies}

Table 6 shows the highest mean score (4.25) is for the statement "When there is difficulty during the listening process, I don't give up, but rather I continue listening." This is crucial while listening, so that the students continue their listening with less tension and more concentration (Goh, 2002). Furthermore, Goh (2002) believes that some metacognitive strategies are beneficial while listening such as lowering the anxiety and encouraging relaxation during listening. The results of the current study reveal that the students very frequently use the strategy of relaxing to reduce anxiety so that their mental focus increases. The lowest mean score in this phase is (3.90) and is recorded for the strategy of "skipping over words that are not understood so the students don't miss what is said next". The students may not prefer to use this strategy as it makes them feel unsafe to skip over words that might be important for figuring out the answers.

\subsubsection{After Listening Strategies}

Table 7 demonstrates that the students used the "after listening" strategies frequently and the mean scores range from high degrees of usage (3.40 - 4.19) to very high degrees of usage $(4.20-5)$.

Table 7. Means and Standard Deviations for after Listening Strategies $(n=20)$

\begin{tabular}{lrr}
\hline Statements & $M$ & $S D$ \\
\hline Cognitive Strategies & & \\
1. I re-read the listening test questions to make sure that I have answered & 4.4 & 1.1 \\
all of them. & & \\
2. I review the answers to make sure that I have answered all parts of & 4.3 & .80 \\
$\quad$ each question correctly. & & \\
3. I check the content and the grammatical accuracy of the answers. & 4.2 & .85 \\
4. I re-read the directions of the listening test to make sure that each & 4.1 & .85 \\
$\quad$ section of the test is completed correctly. & 3.9 & 1.2 \\
5. I make sure that all answers are in the space provided. & & \\
\hline $\begin{array}{l}\text { Metacognitive Strategies } \\
\text { 1. I try to identify the problems/difficulties that I experienced with the }\end{array}$ & 4.2 & 1.0 \\
listening test. & & \\
2. I evaluate how much I have understood of the whole test. & 4.0 & 1.2 \\
\hline
\end{tabular}

\subsection{Cognitive Strategies}

Table 7 shows that with regard to cognitive strategies, the highest mean score (4.40) is recorded for the statement "I re-read the listening test questions to make sure that I have answered all of them." This shows that the students check their answers after they finish their listening to avoid missing any of the questions. However, the lowest mean score (3.95) is recorded for the statement "I make sure that all answers are in the space provided", which 
shows that the students may perceive using this strategy as similar to the strategy of making sure that they have answered all of the questions of the test.

\subsection{Metacognitive Strategies}

Regarding the metacognitive strategies, table 7 shows that the highest mean score (4.25) is recorded for the statement "I try to identify the problems and difficulties that I experienced with the listening test." This indicates that the students tend to reflect upon the content and problems they experienced during the listening tests. This finding goes with what Vahdany et al. (2016) expressed in their study regarding the importance of teaching students how to reflect on the listening process they experience.

In general, the results of the questionnaire are in accordance with some findings of Goh (2002), Vandergrift (2003), Vahdany et al. (2016), Kassem (2015), Riazi (2007), Harputlu and Ceylan (2014), and Ostovar-Namaghi (2016) who found that the students with frequent overall strategy use, including cognitive strategies and metacognitive strategies, outperformed their counterparts who used the strategies infrequently.

Furthermore, some informal interviews were conducted with some of the experimental group students which revealed that using some of the test taking strategies helped them in better comprehending the listening presentation. This was a reason for getting better marks in the post listening test. For example, one of the students said, "using the strategies before listening like translating the questions, helped me to understand the questions and enabled me to comprehend the listening presentation, which in return increased my correct answers in the test." Also, most of the interviewed students mentioned that although they know some of the test taking strategies, they were unaware of the value of using them on tests generally and on listening tests specifically. This finding is consistent with what Al-Saifi (2008) found in her study. The teacher of the experimental group also mentioned that her students were doing better in the listening lessons that were not related to the experiment. This could be attributed to the effect of learning the test taking strategies.

\section{Discussion}

Research has suggested that there is a strong positive relationship between students' achievement in the listening comprehension tests and the use of test taking strategies (Ahour \& Bargool, 2015; Goh, 2002; Kassem, 2015; Rahimi \& Katal, 2012; Riazi, 2007; Vahdany et al., 2016). The results of the present study came in support of these studies; the intervention implemented resulted in an improvement in the experimental students' performance in listening tests compared with the control group, hence the effectiveness of using test taking strategies. Thus, equipping students with a range of test taking strategies that they can use both in their listening lessons and in listening comprehension tests has a positive impact on their performance as suggested by the findings of this study.

Also, research suggests that varying the type of test taking strategies is considered more effective in the listening comprehension tests (Vandergrift, 2011; Rahimirad, 2014). In this 
study, the results of the students' perceptions showed that the students perceived using test taking strategies in listening comprehension tests as very beneficial not only in listening but also in other language skill areas like reading. In addition, the use of these strategies can expand to other subjects like mathematics and Arabic as stated by Al-Saifi (2008). Furthermore, training students to use new strategies is enjoyable, makes them feel enthusiastic and helps them gain more scores as well. This is also stressed by Amer (1993), Bait-Obiedoon (2002), and Al-Saifi (2008).

Additionally, the results of the questionnaire of this study showed that the students used some strategies more than others. In this study, during the "before listening" phase, the results showed that the students highly used both cognitive strategies and affective strategies, while in the "during listening" phase the results revealed that the students used cognitive strategies more than the metacognitive strategies and this was the case in the "after listening" phase. This shows that the use of cognitive strategies is more evident in all of the three phases and this stresses the importance of training the students to use more cognitive strategies without neglecting the teaching of metacognitive and affective strategies as well.

\section{Limitations and Implications}

The scope of this study was limited to the population of grade11 female students in $\mathrm{Al}$ Batinah North Governorate in the 2016-2017 academic year. The study has several implications and recommendations for practice and for further research.

\subsection{Implications for Practice}

Using test taking strategies is considered to be critical in the field of listening comprehension tests (Rahimirad, 2014; Vahdany et al., 2016; Goh, 2000). Thus, effective training courses that help teachers incorporate test taking strategies in their classrooms are required. This measure will aid the teachers in improving their practices in addressing listening skills. It will also help them raise their students' awareness of using test taking strategies in listening comprehension as well as using such strategies in other skill areas like reading and even expand to other subjects as suggested by Al-Saifi (2008). Furthermore, such training courses will provide students with strong and effective test taking strategies and will encourage them to apply the cognitive, metacognitive, and affective strategies consciously. This is also recommended in the study conducted by Vahdany et al. (2016) and Pan and In'nami (2015). Also, Oxford (2003) proposed that skillful teachers can help their students to be aware of various strategies and enable them to use them appropriately.

Moreover, the findings of the current study revealed that using test taking strategies for listening comprehension tests had a positive effect on the students' achievement. Therefore, the Ministry of Education (MOE) should cultivate the use of test taking strategies in the listening comprehension curriculum. The results of the study further showed that even the performance of the students in the control group had improved. This may be due to the practice they received during the experiment. This suggests that the students should be provided with more listening sessions in order to practice this skill. Therefore, the MOE 
should increase the listening lessons in the syllabus. Additionally, the results of the students' perceptions questionnaire revealed that the students perceived the use of the test taking strategies as being very important. They used the strategies at a high rate. This suggests that there should be a concentration on the strategies used most often by the students, which in this case were the cognitive and metacognitive strategies. In fact, this is also recommended by Vahdany et al. (2016). They suggested that there is a crucial need to teach and encourage the EFL students to use the cognitive and metacognitive strategies.

\subsection{Implications for Further Studies}

Further research is needed to investigate the strategies most employed by the students that also improved their performance, as these strategies need to be integrated in a way that make them more efficient for listening comprehension, as suggested by Vandergrift (2003). Also, other factors could be investigated such as the use of test taking strategies across gender and students' proficiency levels. Further research can also look at test taking strategies in other language skills in Omani EFL classes. Also, more empirical studies are needed to gain insights regarding the most effective test taking strategies that can positively affect the students' achievement in listening comprehension tests. Finally, investigating the teachers' and the students' perceptions towards using the affective strategies in listening comprehension is required because this study was limited in this regard.

\section{Conclusion}

Using test taking strategies is considered to be critical in the field of listening comprehension tests (Goh, 2000; Rahimirad, 2014; Vahdany et al., 2016). Since the use of these strategies is relatively neglected in the Omani context, this study aimed to investigate the effect of using such strategies on grade 11 students. It intended to find out whether there is an effect of using test taking strategies in listening comprehension tests and the results revealed that the use of test taking strategies in the listening comprehension tests had positive effects in increasing the students' performance. Also, this study aimed to analyze the students' perceptions of using the test taking strategies in the listening comprehension tests and the findings indicated that the students perceived using the test taking strategies to be very important. Also, the results of the questionnaire showed that the students' use of the various kinds of cognitive, metacognitive, and affective strategies for all phases of listening ranged from high to very high degrees of use.

\section{References}

Ahour, T., \& Bargool, S. (2015). A comparative study on the effects of note taking during listening and post-listening summary writing on Iranian EFL learners' listening comprehension. Theory and Practice in Language Studies, 5(11), 2327-2332. http://dx.doi.org/10.17507/tpls.0511.17

Al Mamari, K. (2009). The Effect of Mobile Learning Technologies on Students' Listening 
Skills in Higher Education in the Sultanate of Oman (unpublished Master's Thesis). Sultan Qaboos University, Muscat, Sultanate of Oman.

Al-Busaidi, S. (1997). An Investigation into the Causes of Students' Listening Comprehension Problems in English at Secondary Level in two Schools in Sultanate of Oman (unpublished Master's Thesis). Exeter University, Exeter, United Kingdom.

Aldera, A. (2015). Investigating multimedia strategies to aid L2 listening comprehension in EFL environment. Theory and Practice in Language Studies, 5(10), 1983-1988. http://dx.doi.org/10.17507/tpls.0510.02

Al-Saifi, S. (2008). The Effect of Test-Taking Strategies Instruction on Test Performance and Test Anxiety of EFL Basic Education Students in Oman (unpublished Master's Thesis). Sultan Qaboos University, Muscat, Sultanate of Oman.

Amer, A. A. (1993). Teaching EFL students to use a test-taking strategy. Language Testing, 10(1), 71-77.

Amer, A. A. (2007). EFL/ESL test-wiseness and test-taking strategies. ERIC. Retrieved on March 22, 2018 from http://files.eric.ed.gov/fulltext/ED497399.pdf

Aryadoust, V. (2012). Differential item functioning on performance during listening tests: The case of the International English Language Testing System (IELTS) Listening module. International Journal of Listening, 1(26), 40-60. https://doi.org/10.1080/10904018.2012.639649

Aryadoust, V., Goh, C., \& Lee, O. (2011). An investigation of differential item functioning in the MELAB Listening Test. Language Assessment Quarterly, 8(4), 361-385. https://doi.org/10.1080/15434303.2011.628632

Bachman, F. (1990). Fundamental Considerations in Language Testing. Oxford, England: Oxford University Press.

Bachman, F., \& Palmer, S. (1996). Language Testing in Practice. Oxford, England: Oxford University Press.

Bait-Obiedoon, H. (2002). Identifying test-taking strategies of second secondary school students and their attitudes towards English tests (unpublished Master's Thesis). Sultan Qaboos University, Muscat, Sultanate of Oman.

Barkaoui, K., Brooks, L., Swain, M., \& Lapkin, S. (2013). Test-takers' strategic behaviors in independent and integrated speaking tasks. Applied Linguistics, 34, 304-324. https://doi.org/10.1093/applin/ams046

Chamot, A. (2004). Issues in language learning strategy research and teaching. Electronic Journal of Foreign Language Teaching, 1(1), 14-26.

Cohen, A. (2007). Test-taking strategies. Language Testing, 89.

Cohen, A. (2007). The coming age for research on test-taking strategies. In J. Fox, M. 
Wesche, \& D. Bayliss (Eds.), Language Testing Reconsidered. University of Ottawa.

Cohen, J. (1988). Statistical Power Analysis for the Behavioral Sciences (2 ${ }^{\text {nd }}$ Ed.). Hillsdale, N.J: Lawrence Erlbaum.

Coskun, A. (2010). The effect of metacognitive strategy training on the listening performance of beginner students. Research on Youth and Language, 4(1), 35-50.

Cross, J. (2009). Effects of listening strategy instruction on news video text comprehension. Language Teaching Research, 13, 151-176. http://journals.sagepub.com/doi/10.1177/1362168809103446

Dodeen, H. (2009). Test-related characteristics of UAEU students: Test-anxiety, test-taking skills, guessing, attitudes towards tests, and cheating. Journal of Faculty of Education, 26, 31-66.

Dodeen, H., Abdelfattah, F., \& Alshumrani, S. (2014). Test-taking skills of secondary students: The relationship with motivation, attitudes, anxiety, and attitudes towards tests. South African Journal, 34(2).

Goh, C. (2000). A cognitive perspective on language learners' listening comprehension problems. System, 28(1), 55-75. https://doi.org/10.1016/S0346-251X(99)00060-3

Goh, C., \& Aryadoust, V. (2010). Investigating the construct validity of MELAB listening test through the Rasch analysis and correlated uniqueness modelling. In Spaan fellowship working papers in second of foreign language assessment, 8(1), 31-68.

Haladyna, M., \& Downing, M. (2004). Construct-irrelevant variance in high-stakes testing. Educational Measurement Issues and Practices, 23, 17-27.

Harputlu, L., \& Ceylan, E. (2014). The effects of motivation and metacognitive strategy use on EFL listening proficiency. Procedia - Social and Behavioral Sciences, 158, 124-131. https://doi.org/10.1016/j.sbspro.2014.12.056

Hayati, A., \& Jalilifar, A. (2009). The Impact of note-taking strategies on listening comprehension of EFL learners. English Language Teaching, 2(1), 101-111.

Hinkel, E. (2006). Current perspectives on teaching the four skills. TESOL Quarterly, 40(1), 109-131.

Liu, H. J. (2008). A study of the interrelationship between listening strategy use, listening proficiency levels, and learning style. RARECLS, 5, 84-104.

O’Malley, J., \& Chamot, A. (1990). Learning strategies in second language acquisition. London: Cambridge University Press.

O’Malley, J., Chamot, A., \& Kupper, L. (1989). Listening comprehension strategies in second language acquisition. Applied Linguistics, 10, 418-437.

Ostovar-Namaghi, S. (2016). The effect of test taking strategies on EFL learners' listening proficiency gains. Theory and Practice in Language Studies, 6(3), 577-580. 
Oxford, R. (1990). Language Learning Strategies: What Every Teacher Should Know. Boston: Heinle and Heinle.

Pan, Y., \& In'nami, Y. (2015). Relationships between strategy use, listening proficiency level, task type, and scores in an L2 Listening Test. The Canadian Journal of Applied Linguistics, 18(2), 45-77.

Rahimi, M., \& M. Katal. (2012). Metacognitive listening strategies awareness in learning English as a foreign language: A comparison between university and high school students. Social and Behavioral Sciences, 31(1), 82-89.

Rahimirad, M. (2014). The impact of metacognitive strategy instruction on the listening performance of university students. Procedia- Social and Behavioral Sciences, 98, 1485-1491.

Riazi, A. (2007). Language learning strategy use: Perceptions of female Arab English majors. Foreign Language Annals, 40(3), 433-440.

Vahdany, F., Akbari, E., Shahrestani, F., \& Askari, A. (2016). The Relationship between Cognitive and Meta-cognitive Strategy Use and EFL Listening Test Performance. Theory and Practice in Language Studies, 6(2), 385-391. http://dx.doi.org/10.17507/tpls.0602.22

Vandergrift, L. (1997). The comprehension strategies of second language (French) listeners: A descriptive study. Foreign Language Annals, 30, 387-409.

Vandergrift, L. (2003). Orchestrating strategy use: Towards a model of the skilled L2 listener. Language Learning, 53(3), 463-496.

Vandergrift, L. (2011). Listening: Theory and practice in modern foreign language competence. Retrieved on March 20, 2018 from Centre for Languages, Linguistics and Area Studies: www.llas.ac.uk/resources/gpg/67

Vandergrift, L., \& Tafaghodtari, M. (2010). Teaching L2 learners how to listen does make a difference: an empirical study. Language Learning, 60(2), 470-497.

Y1lmaz, H., \& Yavuz, A. (2015). The problems young learners encounter during the practice of listening skills. Social and Behavioral Sciences, 197, 2046 - 2050. http://dx.doi.org/10.1016/j.sbspro.2015.07.570

Young, M. Y. C. (1997). A serial ordering of listening comprehension strategies used by advanced ESL learners in Hong Kong. Asian Journal of English Language Teaching, 1, $35-53$. 


\section{Macrothink}

\section{APPENDIX}

\section{Before listening strategies}

\section{Direct strategies}

Cognitive strategies

1. Previewing the whole listening test before beginning to listen.

2. Reading the directions of the listening test extremely carefully before answering the test.

3. Listening to the directions of the listening test very carefully before completing the test.

4. Translating the instructions into Arabic.

5. Taking notes on the test paper.

6. Utilizing grammatical structures to guess the meaning of the text.

\section{Affective strategies}

Lowering anxiety and relaxing before starting the test.

During listening strategies:

Direct strategies

Cognitive strategies

1. Paying attention to repetitious words in the test.

2. Trying to understand the main idea before considering the details.

3. Considering the voice intonation and the word stress to guess the vocabulary and text.

4. Using visualization to comprehend the text.

5. Relating any new words with words that are already known.

6. Utilizing previously gained knowledge and experience to understand the text.

7. Repeating the words or phrases that have been heard.

8. Summarizing or making an outline for what the students hear.

9. Taking notes and translating what is heard while listening.

Indirect strategies

Metacognitive strategies

1. Listening to the script with eyes closed.

2. Using relaxation to reduce anxiety and increase concentration.

3. Persevering through difficult moments in the listening process.

4. Listening to what is said without paying excessive attention to every new word.

5. Skipping over words that are not understood so that the student can grasp whatever is said next. 
6. Predicting the incoming content by using the information being delivered.

7. Comparing what is understood with what is known about the topic.

After listening strategies:

Direct strategies

Cognitive strategies

1. Re-reading the listening test questions to ensure nothing is left out.

2. Making sure that all answers are given within the space provided.

3. Re-reading the directions to make sure that each section of the test is completed correctly.

4. Reviewing the answers to ensure that each question is answered correctly and completely.

5. Checking the content and grammar of each answer.

Indirect strategies

Metacognitive strategies

1. Evaluating how much of the entire test is understood.

2. Trying to identify the problems/difficulties that are experienced with the listening test.

\section{Copyright Disclaimer}

Copyright for this article is retained by the author(s), with first publication rights granted to the journal.

This is an open-access article distributed under the terms and conditions of the Creative Commons Attribution license (http://creativecommons.org/licenses/by/3.0/). 